\title{
PENGARUH KOMITE AUDIT TERHADAP KINERJA PERUSAHAAN MELALUI MANAJEMEN LABA SEBAGAI VARIABEL INTERVENING
}

\section{(STUDI EMPIRIS PERUSAHAAN GO PUBLIK DI BEI YANG MENGELUARKAN SAHAM SYARIAH)}

\author{
Mohammad Makhrus \\ Program StudiAkuntansiSyariah \\ SekolahTinggiEkonomi Islam SEBI \\ Email: cah_mrs@ymail.com
}

\begin{abstract}
This study aimed to assess whether the presence of audit committees on Go Public companies have a significant influence on company performance. And whether earnings management as an intervening variable in effect. The research data was taken from the annual report in 2010, with a population of firms that go on the list of Islamic securities (DES) to sample as many as 31 companies and analyzed by regression analysis. From the test results empirically prove that the audit committee did not significantly influence the performance of the company, it is seen from the significant variables of the audit committee (KA) of 0.262 is greater than 0.05. Furthermore earnings management (DTACC) an intervening variable in part to the influence of the audit committee (KA) on the performance of the company (Tobins-Q).
\end{abstract}

Keyword : Audit Commite, Earning Manajemen, Performance of the Company.

\section{PENDAHULUAN}

Corporate Governance merupakan susunan aturan yang menentukan hubungan antara pemegang saham, manajer, kreditor, pemerintah, karyawan dan stakeholder internal dan eksternal yang lain sesuai dengan hak dan tanggung jawabnya (FCGI, 2003).

Dengan adanya sistem Corporate Governance para pemegang saham dan inverstor menjadi yakin akan memperoleh return atas investasinya, karena Corporate Governance akan dapat memberikan perlindungan efektif bagi para pemegang saham dan investor. Corporate Governance juga dapat membantu dalam menciptakan lingkungan yang kondusif demi terciptanya pertumbuhan yang efisien dalam perusahaan.

Akuntabilitas sebagai aspek Good Corporate Governance (selanjutnya disebut GCG) sangat penting ketika manajemen menghadapi intertemporal choice (pilihan antar waktu, hal ini berkenaan dengan bagaimana perusahaan mengelola pengeluaran-pengeluaran yang akan memberikan manfaat di masa depan) yang memaksa manajemen melakukan manipulasi karena situasi yang 
dihadapinya. Salah satu contoh manipulasi tersebut adalah dengan mengubah laporan keuangan dengan tujuan menyesatkan pemegang saham yang ingin mengetahui kinerja ekonomi perusahaan atau untuk mempengaruhi hasil kontraktual yang mengandalkan angka akuntansi yang dilaporkannya. Manipulasi yang dikenal dengan earning management antara lain dilakukan dengan memilih prosedur dan metode akuntansi tertentu atau mengendalikan berbagai accrual. Beberapa peneliti sebelumnya telah membuktikan bahwa manajemen melakukan pilihan discreationary accrual (hal ini berkenaan dengan bagaimana perusahaan dalam mengelola pengeluaran-pengeluaran yang akan memberikan manfaat di masa depan. Misalnya, jika perusahaan ingin mengusahakan laba yang lebih besar dari suatu periode akuntansi, maka perusahaan dapat menunda pengakuan biaya penelitian dan pengembangan) untuk kepentingan manajemen (Watts dan Zimmerman, 1986).

Untuk mengawasi pihak manajemen agar tidak melakukan manajemen laba maka dibutuhkan penerapan GCG yang efektif. Salah satu komponen penting dalam pelaksanaan GCG efektif adalah adanya komite audit yang berkualitas. Tugas dan tanggung jawab dari komite audit adalah memastikan prinsip-prinsip GCGyang berkaitan dengan transparansi dan disclousure telahditerapkan secara konsisten dan memadai. Penerapan prinsip ini berkaitan dengan integritas laporan keuangan antara lain terlihat dari ketiadaan permasalahan dalam isi dan penyajian laporan keuangan. Permasalahan dalam pelaporan keuangan perusahaan publik dapat dilihat dari adanya sanksi dari Badan Pengawas Pasar Modal (BAPEPAM).

Urgensi keberadaan komite audit ada pula kaitannya dengan belum optimalnya peran pengawasan yang diemban dewan komisaris di banyak perusahaan di negara-negara korban krisis yang lalu. Indonesia khususnya semakin diperparah dengan adanya karakteristik umum yang melekat pada entitas bisnis kita berupa pemusatan kontrol atau pengendalian kepemilikan perusahaan di tangan pihak tertentu atau segelintir pihak saja (Mayangsari, 2003).

Dari gambaran sederhana mengenai pentingnya tugas dan fungsi dari komite audit, sudah barang tentu, keberadaan komite audit yang berkualitas menjadi sangat penting sebagai salah satu perangkat utama dalam penerapan GCG. Keberadaannya dipertegas dengan Peraturan Bapepam No. IX.1.5 tentang Pembentukan dan Pedoman Pelaksanaan Kerja Komite Audit (Lampiran Keputusan Ketua Bapepam No. Kep-29/PM/2004 tanggal 24 September 2004) juncto Peraturan Bapepam No. X.K.6 tentang Kewajiban Penyampaian Laporan Tahunan Bagi Emiten atau Perusahaan Publik (Lampiran Keputusan Ketua Bapepam No. Kep-134/BL/2006 tanggal 7 Desember 2006), dan Peraturan Bursa Efek Jakarta (sekarang bernama Bursa Efek Indonesia) No. I-A tentang Ketentuan Umum Pencatatan Efek Bersifat Ekuitas Di Bursa (Lampiran II Keputusan Direksi PT Bursa Efek Jakarta No. Kep-305/BEJ/07-2004 tanggal 19 Juli 2004).

Tugas pokok dari komite audit pada prinsipnya adalah membantu dewan komisaris dalam melakukan fungsi pengawasan atas kinerja perusahaan. Hal tersebut terutama berkaitan dengan review sistem pengendalian intern 
perusahaan, memastikan kualitas laporan keuangan dan meningkatkan efektivitas fungsi audit. Kualitas komite audit dalam mengerjakan fungsinya diharapkan dapat mengurangi sifat opportunistic manajemen yang melakukan manajemen laba (earnings management). Selain itu, keberadaan komite audit juga diharapkan mampu meningkatkan kualitas pengawasan internal perusahaan, serta mampu mengoptimalkan mekanisme checks and balances, yang pada akhirnya ditujukan untuk memberikan perlindungan yang optimum kepada pemegang saham dan stakeholder lainnya. Untuk membangun peran dan fungsi tersebut, maka prinsip dan landasan yang harus dipegang oleh Komite Audit meliputi independensi, transparansi dan disclosure, akuntabilitas dan tanggung jawab, serta sikap adil.

Dari peran dan fungsi komite audit tersebut telah banyak penelitian sebelumnya diantaranya De Zoort et al. (2002) dalam Fitriasari (2007) menjelaskan bahwa komite audit yang efektif ditentukan dua hal, yaitu pertama dari sisi input (komposisi kualifikasi, kewenangan dan jumlah sumber daya) serta kedua dari sisi proses (harus memiliki etos kerja yang tinggi). Dari input dan proses tersebut diharapkan komite audit dapat efektif bekerja sehingga bisa menghasilkan suatu output berupa laporan keuangan, internal kontrol dan manajemen resiko yang bisa dipercaya.

Mayangsari dan Murtanto (2002), dalam penelitiannya juga menjelaskan bahwa pembentukan komite audit sebagai komponen penting dalam corporate governance di Indonesia, membuktikan adanya reaksi pasar yang positif dalam menarik investor di pasar.

Klein (2002) dalam penelitiannya memberikan bukti secara empiris bahwa perusahaan yang membentuk komite audit independen melaporkan laba dengan kandungan akrual diskresioner yang lebih kecil dibandingkan dengan perusahaan yang tidak membentuk komite audit independen. Sam'ani (2008) menguji pengaruh GCG (dengan proksi komite audit) terhadap kinerja keuangan dan hasilnya signifikan. Selanjutnya penelitian oleh Hastuti (2005) membuktikan bahwa tidak terdapat hubungan yang signifikan antara corporate governance yang diwakili oleh proksi manajemen laba terhadap kinerja keuangan. Paramita (2008) memberikan bukti bahwa 72 perusahaan manufaktur yang memiliki komite audit tidak ada hubungan yang signifikan terhadap kinerja perusahaan.

Namun dari beberapa penelitian tersebut, penerapan GCG hanya diimplemntasikan untuk perusahaan yang belum mengeluarkan saham syariah. Oleh karena itu penelitian ini mencoba meneliti pada perusahaan yang khusus mengeluarkan saham syariah. Dalam hal ini perusahaan yang dimaksud adalah perusahaan yang terdaftar dalam Daftar Efek Syariah (selanjutnya disebut DES). Hal ini disebabkan DES sudah dikategorikan sharia compliance atau yang dinyatakan tidak bertentangan dengan syari'at Islam oleh DSN-MUI. Selain itu, DES merupakan salah satu instrumen dalam pengembangan pasar modal syariah di Indonesia. 


\section{RUMUSAN MASALAH}

Banyak penelitian telah menelaah tentang komite audit dan good corporate governance (GCG) dengan berbagai coraknya, Klein (2002) memberikan bukti secara empiris bahwa perusahaan yang membentuk komite audit melaporkan laba dengan kandungan akrual diskresioner yang lebih kecil dibandingkan dengan perusahaan yang tidak membentuk komite audit independent. Paramita (2008) memberikan bukti terhadap 72 perusahaan manufaktur yang memiliki komite audit tidak ada hubungan yang signifikan antara komite audit terhadap kinerja keuangan. Penelitian oleh Hastuti (2005) membuktikan bahwa tidak terdapat hubungan yang signifikan antara corporate governance yang diwakili oleh proksi manajemen laba terhadap kinerja keuangan.

Berdasarkan pemaparan diatas, penelitian tersebut masih banyak menggunakan sampel perusahaan umum dan masih sedikit penelitian pada perusahaa publik yang mengeluarkan saham syariah sebagai sampel penelitian. Karakteristik Islami yang harus inherent dengan prinsip-prinsip syariah, baik sumber daya manusia maupun aktifitas operasional, maka idealnya komite audit berpengaruh signifikan terhadap kinerja pasar perusahaan pada perusahaa publik yang mengeluarkan saham syariah.

Dari uraian tersebut, maka dapat ditarik pertanyaan yang diajukan dalam penelitian ini sebagai berikut:

1. Apakah komite audit berpengaruh signifikan terhadap kinerja perusahaan yang mengeluarkan saham syariah yang terdaftar di DES periode 2010?

2. Apakah komite audit berpengaruh signifikan terhadap manajemen laba?

3. Apakah manajemen laba berpengaruh signifikan terhadap dengan kinerja perusahaan?

4. Apakah manajemen laba merupakan variable intervening pengaruh komite audit terhadap kinerja perusahaan yang mengeluarkan saham syariah?

\section{KAJIAN LITERATUR}

\subsection{KOMITE AUDIT}

Komite audit adalah salah satu komite yang dibentuk oleh dewan komisaris dan bertanggungjawab kepada dewan komisaris dengan tugas dan tanggungjawab utama untuk memastikan prinsip-prinsip good corpotare governance terutama transparansi dan disclosure diterapkan secara konsisten dan memadai oleh para eksekutif (Tjager et al., 2003).

Komite audit mempunyai peran yang sangat penting dan strategis dalam hal memelihara kredibilitas proses penyusunan laporan keuangan seperti halnya menjaga terciptanya sistem pengawasan perusahaan yang memadai serta dilaksanakannya good corporate governance. Dengan berjalannya fungsi komite audit secara efektif, maka control terhadap perusahaan akan lebih baik sehingga, konflik keagenan yang terjadi akibat keinginan manajemen untuk meningkatkan kesejahteraannya sendiri dapat diminimalisasi. 
Komite audit bertugas membantu dewan komisaris untuk memonitor proses pelaporan keuangan oleh manajemen untuk meningkatkan kredibilitas laporan keuangan (Bradbury et al., 2004). Tugas komite audit meliputi menelaah kebijakan akuntansi yang diterapkan oleh perusahaan, menilai pengendalian internal, menelaah sistem pelaporan eksternal dan kepatuhan terhadap peraturan. Di dalam pelaksanaan tugasnya komite menyediakan komunikasi formal antara dewan, manajemen, auditor eksternal dan auditor internal (Bradbury et al., 2004). Adanya komunikasi formal antara komite audit, auditor internal, dan auditor eksternal akan menjamin proses audit internal dan eksternal dilakukan dengan baik. Proses audit internal dan eksternal yang baik akan meningkatkan akurasi laporan keuangan dan kemudian meningkatkan kepercayaan terhadap laporan keuangan (Anderson et al., 2003).

Dari penjelasan tersebut dapat disimpulkan bahwa komite audit dapat mengurangi aktivitas earning management yang selanjutnya akan mempengaruhi kualitas pelaporan keuangan yang salah satunya adalah kualitas laba.

Kalbers dan Fogarty (1993) menyebutkan tiga faktor yang mempengaruhi keberhasilan komite audit dalam menjalankan tugasnya yaitu 1) kewenangan formal dan tertulis, 2) kerjasama manajemen dan 3) kualitas/kompetensi anggota komite audit. Selain itu, Effendi (2005) juga menambahkan masalah komunikasi dengan komisaris, direksi, auditor internal dan eksternal serta pihak lain sebagai aspek yang penting dalam keberhasilan kerja komite audit. Dengan kewenangan, independensi, kompetensi dan komunikasi melalui pertemuan yang rutin dengan pihak-pihak terkait, diharapkan fungsi dan peran dari komite audit lebih bisa berjalan dengan efektif sehingga dapat mengidentifikasi kemungkinan adanya praktek manajemen laba yang oportunistik.

Kelley et al., (2005) menemukan bukti bahwa predicted component of abnormal current accruals yang berkaitan dengan komite audit (independensi dan aktivitas) berhubungan positif dengan arus kas perusahaan satu tahun ke depan. Penelitian ini memberikan bukti bahwa manajemen laba yang dilakukan perusahaan lebih bersifat efisien. Sedang penelitian di Indonesia oleh Siregar dan Utama (2005), Siregar P(2005) serta Paramita (2008) menunjukkan kecenderungan bahwa keberadaan komite audit ternyata tidak berpengaruh terhadap jenis manajemen laba perusahaan.

\subsection{KINERJA PERUSAHAAN}

Kinerja adalah kemampuan kerja yang ditunjukkan dengan hasil kerja. Hawkins (The Oxford Paperback Dictionary, 1979) mengemukakan pengertian kinerja sebagai berikut: "Performance is: (1) the process or manner of performing, (2) a notable action or achievement, (3) the performing of a play or other entertainment".

Penilaian yang dibutuhkan perusahaan tidak hanya dari investor saja, namun juga dari kreditor. Semakin besar pinjaman yang diberikan kreditor, menunjukkan bahwa semakin tinggi kepercayaan yang diberikan, hal ini 
menunjukkan perusahaan mamiliki nilai pasar yang lebih besar lagi. Dengan dasar tersebut, Tobin's Q menggunakan Market value of total assets.

Rumus :

$$
\text { Tobins } Q=\frac{M V A+D E B T}{T A}
$$

Keterangan:

MVE = harga penutupan saham di akhir tahun buku $\mathrm{x}$ jumlah saham biasa yang beredar

DEBT $=($ utang lancar - aktiva lancar $)+$ nilai buku persediaan + utang jangka panjang

$\mathrm{TA}=$ nilai buku total aktiva

Menurut James Tobin, apabila Q-tobin > 1 menunjukkan bahwa perusahaan menghasilkan earning dengan rate of return yang sesuai dengan harga perolehan asset-asetnya (Klapper and Love, 2002) dalam Paramita(2008).

\subsection{GOOD CORPORATE GOVERNANCE}

Price Waterhouse Coopers (2000) Corporte governance terkait dengan pengambilan keputusan yang efektif dibangun melalui kultur organisasi, nilainilai, sistem, berbagai proses, kebijakan-kebijakan dan struktur organisasi, yang bertujuan untuk mencapai bisnis yang menguntungkan, efisien dan efektif dalam mengelola resiko dan bertanggung jawab dengan memerhatikan kepentingan stakeholders.

Indonesia mulai menerapkan prinsip GCG sejak menandatangani letter of intent (LOI) dengan IMF, yang salah satu bagian pentingnya adalah pencantuman jadwal perbaikan pengelolaan perusahaan-perusahaan di Indonesia (YPPMI \& SC, 2002). Sejalan dengan hal tersebut, Komite Nasional Kebijakan Corporate Governance (KNKCG) berpendapat bahwa perusahaanperusahaan di Indonesia mempunyai tanggung jawab untuk menerapkan standar GCG yang telah diterapkan di tingkat internasional. Namun, walau menyadari pentingnya GCG, banyak pihak yang melaporkan masih rendahnya perusahaan yang menerapkan prinsip tersebut. Masih banyak perusahaan menerapkan prinsip GCG karena dorongan regulasi dan menghindari sanksi yang ada dibandingkan yang menganggap prinsip tersebut sebagai bagian dari kultur perusahaan.

\subsection{HUBUNGAN ANTARA KOMITE AUDIT DENGAN KINERJA PERUSAHAAN}

Masalah keagenan sebenarnya muncul ketika principil kesulitan untuk memastikan bahwa agen bertindak untuk memaksimumkan kesejahteraan principal. Menurut teori keagenan (agency theory) salah satu mekanisme yang secara luas digunakan dan diharapkan dapat menyelaraskan tujuan principal dan agen adalah melalui mekanisme pelaporan keuangan. Menurut Blue Ribbon Committee (1999, p.22) beberapa studi baru menghasilkan korelasi antara independensi komite audit dan dua hal yaitu, mengetahui dengan tinggi kekeliruan dan mengurangi kejadian kecurangan dalam laporan keuangan. Sedangkan Nuryanah (2004) dalam Effendi (2005) menemukan bahwa komite 
audit tidak mempengaruhi nilai perusahaan secara signifikan. Namun Effendi (2005) menyimpulkan adanya peranan komite audit dalam meningkatkan kinerja perusahaan, terutama dari aspek pengendalian.

Kinerja perusahaan akan baik jika perusahaan mampu mengendalikan perilaku para eksekutif puncak perusahaan untuk melindungi kepentingan pemilik perusahaan (pemegang saham), salah satunya dengan keberadaan komite audit. Komite audit diharapkan mampu mengawasi laporan keuangan, mengawasi audit eksternal dan mengawasi sistem pengendalian internal sesuai dengan Peraturan Bapepam No. IX.1.5 tentang Pembentukan dan Pedoman Pelaksanaan Kerja Komite Audit (Lampiran Keputusan Ketua Bapepam No. Kep-29/PM/2004 tanggal 24 September 2004) juncto Peraturan Bapepam No. X.K.6 tentang Kewajiban Penyampaian Laporan Tahunan Bagi Emiten atau Perusahaan Publik (Lampiran Keputusan Ketua Bapepam No. Kep-134/BL/2006 tanggal 7 Desember 2006), dan Peraturan Bursa Efek Jakarta (sekarang bernama Bursa Efek Indonesia) No. I-A tentang Ketentuan Umum Pencatatan Efek Bersifat Ekuitas Di Bursa (Lampiran II Keputusan Direksi PT. Bursa Efek Jakarta No. Kep-305/BEJ/072004 tanggal 19 Juli 2004). Karena pertanggungjawaban mereka untuk mengawasi internal control dan laporan keuangan, GCG memerintahkan bahwa komite audit harus memiliki tingkat kompetensi dalam keuangan (BRC,1999).

\subsection{DAFTAR EFEK SYARIAH}

Daftar Efek Syariah (DES) adalah kumpulan Efek yang tidak bertentangan dengan Prinsip-prinsip Syariah di Pasar Modal, yang ditetapkan oleh Bapepam-LK atau Pihak yang disetujui Bapepam-LK. DES tersebut merupakan panduan investasi bagi Reksa Dana Syariah dalam menempatkan dana kelolaannya serta juga dapat dipergunakan oleh investor yang mempunyai keinginan untuk berinvestasi pada portofolio Efek Syariah,

\subsection{PENGEMBANGAN HIPOTESIS DAN PENELITIAN SEBELUMNYA}

Berdasarkan uraian tentang kajian pustaka dan penelitian sebelumnya, maka dapat dibuat rerangka konsep sebagai berikut :

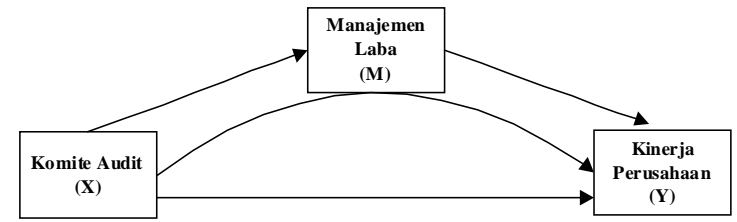

Gambar 2.1 Model pengembangan hipotesa

Atas dasar modifikasi model pada gambar 2.1, maka pengembangan hipotesa diuraikan sebagai berikut:

Komite audit yang bertanggung jawab untuk mengawasi laporan keuangan, mengawasi audit eksternal, dan mengamati sistem pengendalian internal (termasuk audit internal) dapat mengurangi sifat opportunistic manajemen yang melakukan manajemen laba (earnings management) dengan 
cara mengawasi laporan keuangan dan melakukan pengawasan pada audit eksternal.

Beberapa penelitian telah membuktikan bahwa hubungan positif antara kualitas corporate governance dengan kehandalan laporan keuangan. Perusahaan tanpa komite audit lebih mungkin terdapat kecurangan laporan keuangan (Dechow et al,. 1996 dan McMullen, 1996) dan komite audit yang berkualitas mampu membatasi dilakukannya manajemen laba dalam perusahaan (Anderson, 2003). Sedangkan penelitian oleh Hastuti (2005) membuktikan bahwa tidak terdapat hubungan yang signifikan antara corporate governance yang diwakili oleh proksi manajemen laba terhadap kinerja keuangan.

Klein (2002) memberikan bukti secara empiris bahwa perusahaan yang membentuk komite audit independen melaporkan laba dengan kandungan akrual diskresioner yang lebih kecil dibandingkan dengan perusahaan yang tidak membentuk komite audit independen. Kandungan discretionary accruals tersebut berkaitan dengan kualitas laba perusahaan. Sedangkan Parulian (2004) dalam paramita (2008) menyimpulkan bahwa komite audit memiliki hubungan negatif signifikan dengan akrual diskresioner yang negatif, tetapi tidak signifikan dengan akrual diskresioner yang positif.

Penelitian lain mengenai komite audit ada yang mengindikasikan kurang efektifnya keberadaan komite audit sebagai salah satu praktek corporate governance di perusahaan yang terdaftar di BEJ. Mayangsari (2003) meneliti pengaruh keberadaan komite audit terhadap intregitas laporan keuangan, hasilnya keberadaan komite audit berhubungan negatif dengan intregritas laporan keuangan.

Price Waterhouse (1980) dalam Purwati (2006) menyatakan bahwa investor, analis dan regulator menganggap komite audit memberikan kontribusi dalam kualitas pelaporan keuangan. Komite audit meningkatkan integritas dan kredibilitas pelaporan keuangan melalui: (1) pengawasan atas proses pelaporan termasuk sistem pengendalian internal dan penggunaan prinsip akuntansi berterima umum, dan (2) mengawasi proses audit secara keseluruhan. Hasilnya mengindikasikan bahwa adanya komite audit memiliki konsekuensi pada laporan keuangan yaitu: (1) berkurangnya pengukuran akuntansi yang tidak tepat, (2) berkurangnya pengungkapan akuntansi yang tidak tepat dan (3) berkurangnya tindakan kecurangan manajemen dan tindakan illegal.

Informasi akuntansi yang diungkapkan secara transparan (disclosure) serta terjaminnya kualitas pelaporan keuangan yang salah satunya adalah kualitas laba dalam rangka mengurangi manajemen laba melalui efektifitas komite audit akan meningkatkan pencapaian mekanisme corporate governance, dan jika mekanisme corporate governance dilakukan dengan baik maka kinerja perusahaan juga akan semakin meningkat Laporan keuangan yang berkualitas dan bisa dipercaya merupakan sesuatu hal yang sulit diukur. Salah satu cara yang digunakan peneliti untuk mengukurnya yaitu dengan melihat apakah terdapat praktek manajemen laba yang dilakukan oleh pihak manajemen di dalam penyusunan laporan keuangannya, yang diproksi dengan akrual diskresioner (Bradbury et al. (2004). 
Berdasarkan Scott (2003), manajemen laba yang dilakukan perusahaan bisa bersifat good (efisien) ataupun bad (oportunistik). Dengan praktek manajemen laba yang efisien diharapkan reliabilitas dari laporan keuangan perusahaan bisa semakin meningkat. Beberapa penelitian membuktikan bahwa peranan sistem governance yang baik, salah satunya komite audit, dapat membuat jenis manajemen laba perusahaan menjadi lebih efisien. Sedangkan Paramita (2008) dalam penelitiannya tidak menemukan pengaruh dari keberadaan komite audit terhadap jenis manajemen laba yang dilakukan perusahaan.

Oleh karena itu hipotesa yang dikembangkan selanjutnya adalah :

a. Hipotesis pertama

$\mathrm{H}_{0} 1$ : Komite audit tidak berpengaruh signifikan terhadap kinerja perusahaan.

Ha1 : Komite audit berpengaruh signifikan terhadap kinerja perusahaan. b. Hipotesis kedua laba.

$\mathrm{H}_{0} 2$ : Komite audit tidak berpengaruh signifikan terhadap manajemen

$\mathrm{Ha} 2$ : Komite audit berpengaruh signifikan terhadap manajemen laba. c. Hipotesis ketiga

$\mathrm{H}_{0} 3$ : Manajemen laba tidak berpengaruh signifikan terhadap kinerja perusahaan

Ha3 : Manajemen laba berpengaruh signifikan terhadap kinerja perusahaan

\section{METODOLOGIPENELITIAN}

\subsection{JENIS PENELITIAN}

Penilitian ini menggunakan penelitian deskriptif asosiatif yaitu penelitian yang bertujuan untuk menjelaskan pengaruh antara dua variabel atau lebih. Penelitian ini menganalisa pengaruh komite audit terhadap kinerja perusahaan, pengaruh komite audit terhadap manajemen laba, pengaruh manajemen laba terhadap kinerja perusahaan.

\subsection{VARIABEL PENELITIAN DAN DEFINISI OPERASIONAL}

Penelitian ini akan menguji tiga variabel, yaitu kinerja perusahaan, komite audit dan manajemen laba. Kinerja perusahaan sebagai variabel dependen, komite audit sebagai variabel independen serta manajemen laba sebagai variabel dependent dan independen diwakili oleh discretionary total accrual (DTAC). Discretionary total accruals merupakan akrual yang dihitung dari aktiva dan aktiva tetap.

\subsubsection{Variabel Dependen}

Variabel dependen dalam hal ini akan di hitung dengan Tobin's Q. Rasio-rasio keuangan digunakan investor untuk mengetahui nilai pasar perusahaan. Rasio tersebut dapat memberikan indikasi bagi manajemen mengenai penilaian investor terhadap kinerja perusahaan dimasa lampau dan prospeknya dimasa mendatang. 
Ada beberapa rasio untuk mengukur nilai pasar perusahaan, salah satunya Tobin's Q.

Semakin besar nilai rasio Tobin's Q menunjukkan bahwa perusahaan memiliki prospek pertumbuhan yang baik dan memiliki intangible asset yang semakin besar. Hal ini terjadi karena semakin besar nilai pasar aset perusahaan, maka semakin besar kerelaan investor untuk mengeluarkan pengorbanan yang lebih untuk memiliki perusahaan tersebut. Perusahaan dengan nilai Tobin's Q yang tinggi biasanya memiliki brand image perusahaan yang sangat kuat, sedangkan perusahaan yang memiliki nilai Tobin's $Q$ yang rendah umumnya berada pada industry yang sangat kompetitif atau industri yang mulai melemah.

Rumus :

$$
\text { Tobins } Q=\frac{M V A+D E B T}{T A}
$$

Keterangan:

MVE = harga penutupan saham di akhir tahun buku $\mathrm{x}$ jumlah saham biasa yang beredar

DEBT $=$ (utang lancar - aktiva lancar $)+$ nilai buku persediaan + utang jangka panjang

$\mathrm{TA}=$ nilai buku total aktiva

\subsubsection{Variabel Independen}

Variabel Independen dalam penelitian ini adalah komite audit. Komite audit dalam halini diukur menggunakan informasi yang berkaitan dengan pengungkapan komite audit di dalam laporan tahunan. Pengukuran komite audit mengacu pada 21 item pengungkapan yang didasari pada peraturan BAPEPAM no IX.1.5. Pengukuran variabel ini diukur dengan pengungkapan peraturan tentang pedoman pelaksanaan kerja komite audit dengan membandingkan jumlah pengungkapan yang diharapkan. Model pengukuran ini sesuai dengan model pengukuran indeks pengungkapan CSR pada Sri Rahayu (2010) yang membandingkan 78 item dengan jumlah pengungkapan yang diharapkan.

\subsubsection{Variabel Intervening}

Manajemen Laba dalam penelitian ini merupakan variabel dependen dan sekaligus merupakan variabel independent. Manajemen laba dalam penelitian ini berfungsi sebagai variabel intervening. Yakni, variabel yang menjembatani antara variabel dependen dan independent. Menurut Tuckman (dalam Sugiono, 2007) variabel intervening merupakan variabel penyela antara variabel independen dengan variabel dependen, sehingga variabel inependen tidak langsung mempengaruhi berubahnya atau timbulnya variabel dependen.

Manajemen laba adalah manipulasi laba yang dilakukan oleh pihak manajemen dengan menggunakan kebijakan metode akuntansi untuk mencapai tujuan tertentu pribadi atau perusahaan. Deteksi atas kemungkinan dilakukannya manajemen laba dalam laporan keuangan secara umum diteliti melalui penggunaan akrual. Jumlah akrual yang tercermin dalam penghitungan laba terdiri dari discretionary accruals dan nondiscretionary accruals. 
Nondiscretionary accruals merupakan komponen akrual yang terjadi seiring dengan perubahan dari aktivitas perusahaan dan discretionary accrual merupakan komponen akrual yang berasal dari earnings management yang dilakukan manajer.

Manajemen laba dapat diukur melalui discretionary accruals (DACC) yang dihitung dengan cara menselisihkan total accruals (TACC) dengan nondiscretionary accruals (NDACC). Dalam menghitung DACC, digunakan model Modified Jones. Model Modified Jones yang merupakan perkembangan dari model Jones (1991) dapat mendeteksi manajemen laba lebih baik dibandingkan model-model lainnya sejalan dengan hasil penelitian Dechow et al., (1995). Model ini didesain untuk mengeliminasi kecenderungan bias yang dihasilkan oleh model Jones (1991) yang mengasumsikan pendapatan sebagai komponen nondiscretionary accruals. Model ini secara implisit mengasumsikan bahwa segala perubahan pada penjualan kredit pada periode observasi dipengaruhi oleh manajemen laba atau dengan kata lain merupakan komponen discretionary accruals. Dechow et al., (1995) berpendapat manajemen laba memiliki keleluasaan untuk menggunakan diskresinya pada penjualan kredit dalam hal pengakuan pendapatan dibandingkan penjualan tunai.

Beberapa penelitian seperti yang dilakukan Guay et al., (1996), Subramayam (1996), Bowman dan Navissi (1998), dan Halim et al., (2005) dalam Nurrohmah (2010) menyimpulkan bahwa model Modified Jones merupakan model yang paling diapresiasi oleh pasar karena secara signifikan merefleksikan performa dan sikap oportunis manajemen atau paling mencerminkan manajemen laba yang dilakukan. Penentuan discretionary accruals sebagai proksi manajemen laba menggunakan model Modified Jones adalah sebagai berikut:

Total akrual perusahaan terdiri dari komponen nondiscretionary accruals dan discretionary accruals.

$\mathrm{TACC}_{\mathrm{it}} / \mathrm{TA}_{\mathrm{i}, \mathrm{t}-1}=\mathrm{NDACC}_{\mathrm{it}}+\mathrm{DACC}_{\mathrm{it}}$

TACC $_{\text {it }} \quad:$ Total Accruals perusahaan i pada periode $t$

$\mathrm{NDACC}_{\text {it }}$ : Nondiscretionary accruals perusahaan i pada periode $\mathrm{t}$

DACC $_{\text {it }} \quad$ : Discretionary accruals perusahaan i pada periode t

Perhitungan total akrual dengan pendekatan arus kas dan laporan rugi laba dihitung dengan rumus sebagai berikut ini (Sloan: 1996):

$\mathrm{TACC}_{\mathrm{it}}=\mathrm{EBXT}_{\mathrm{it}}-\mathrm{OCF}_{\mathrm{it}}$

$\mathrm{t}$

$\mathrm{EBXT}_{\mathrm{it}}=$ Earning Before Extraordinary Items perusahaan i pada periode

$\mathrm{OCF}_{\text {it }}=$ Operating Cash Flow perusahaan i pada periode $\mathrm{t}$

Setelah mendapatkan nilai total akrual, dilakukan persamaan regresi untuk mengestimasi nilai masing-masing koefisien pada tiap variabel di dalam model berikut:

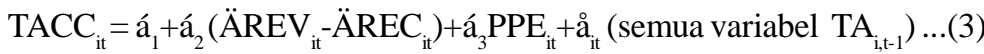

$$
\begin{aligned}
& \mathrm{REV}_{\text {it }} \quad=\text { Revenue perusahaan i pada periode } \mathrm{t} \\
& \mathrm{REC}_{\mathrm{it}} \quad=\text { Receivable perusahaan i pada periode } \mathrm{t} \\
& \mathrm{PPE}_{\mathrm{it}} \quad=\text { Nilai aktiva tetap (gross) perusahaan i pada periode } \mathrm{t} \\
& \mathrm{TA}_{\mathrm{i}, \mathrm{t}-1} \quad=\text { Total aktiva perusahaan i pada periode } \mathrm{t}-1
\end{aligned}
$$


Setelah didapatkan nilai koefisien untuk masing-masing variabel, koefisien tersebut kembali digunakan untuk menghitung nilai NDACC dengan cara sebagai berikut:

$\mathrm{NDACC}=a_{1}\left(1 / \mathrm{TA}_{\mathrm{i}, \mathrm{t}-1}\right)+a_{2}\left(\left(\mathrm{ÄREV}_{\mathrm{it}} \ddot{A ̈ R E C}_{\mathrm{it}}\right) / \mathrm{TA}_{\mathrm{i}, \mathrm{t}-1}\right)+a_{3}\left(\mathrm{PPEit}_{\mathrm{TA}} \mathrm{TA}_{\mathrm{i}, \mathrm{-}-1}\right) \ldots(4)$

Discretionary Accruals didapat dari subtitusi persamaan (4) ke persamaan (1) sebagai berikut:

$\mathrm{DACC}=\mathrm{TACC}_{\mathrm{t}} / \mathrm{TA}_{\mathrm{i},-\mathrm{-}}-\mathrm{NDACCit}$

Jika nilai total akrual perusahaan i pada periode $\mathrm{t}$ (TACCit) sama dengan nondiscretionary accruals (NDACC) atau dengan kata lain discretionary accruals (DACC) sama dengan nol (0) maka tidak ada manajemen laba. Nilai DACC yang positif menandakan praktek manajemen laba dengan menaikkan angka laba, sebaliknya nilai DACC yang negatif menandakan terdapatnya indikasi praktek manajemen laba dengan menurunkan angka laba. Sebagaimana yang diungkapkan Dechow et. al.(1995) Bahwa rekayasa menurunkan laba diindikasikan dengan nilai akrual kelolaan yang negatif dan sebaliknya. Jadi, nilai Discretionary accruals menunjukkan tingkat akrual hasil manajemen laba.

\subsection{POPULASI DAN PENENTUAN SAMPEL PENELITIAN}

Populasi yang digunakan dalam penelitian ini adalah semua perusahaan yang terdaftar di bursa Efek Indonesia pada tahun 2010-2011. Sedangkan perusahaan yang menjadi sampel penelitian ini dipilih berdasarkan kriteria-kriteria tertentu. Teknik pengambilan sampel yang digunakan dalam penelitian ini adalah purposive sampling, yaitu sampel atas dasar kesesuaian karakteristik sampel dengan kriteria pemilihan sampel yang telah ditentukan :

a) Perusahaan yang tidak tergolong dalam kelompok industri properti, real estate dan konstruksi yang mengeluarkan saham syariah yang termasuk dalam daftar efek syariah (DES) periode pengamatan 2010-2011.

b) Perusahaan yang memiliki data komite audit,

c) Perusahaan yang menerbitkan laporan keuangan untuk periode yang berakhir 31 Desember selama periode pengamatan 2010.

Berdasarkan kriteria diatas maka jumlah perusahaan yang dijadikan sampel penelitian sebanyak 31 perusahaan.

\subsection{JENIS DAN SUMBER DATA}

Penelitian ini menggunakan sumber data historis. Dan jenis data yang digunakan adalah data sekunder yang diperoleh secara tidak langsung dari pihak ketiga melalui media perantara dari berbagai sumber yang tersedia. Data tersebut diperoleh dari buku referensi, literatur dan data yang diambil dari laporan tahunan Bursa Efek Indonesia.

Penelitian ini menggunakan data sekunder yang diperoleh dari laporan keuangan pada perusahaan yang telah listed di BEI yang mengeluarkan saham syariah pada periode 2010. Dengan menggunakan data penelitian yang mencakup data periode tahun 2010 itu sudah dipandang cukup untuk mewakili kondisi perusahaan yang mengeluarkan saham syariah di Indonesia saat ini. 


\subsection{METODE ANALISIS DATA}

\subsubsection{Pengujian Asumsi Klasik}

Pengujian asumsi klasik bertujuan untuk mengetahui dan menguji kelayakan atas model regresi yang digunakan untuk penelitian ini. Pengujian ini juga dimaksudkan untuk memastikan bahwa di dalam model regresi yang digunakan tidak terdapat autokolerasi, multikolonieritas, dan heteroskedastisitas serta untuk memastikan bahwa data yang dihasilkan berdistribusi normal (Ghozali,2005).

\subsection{PENGUJIAN HIPOTESIS}

Berdasarkan hasil dari penelitian-penelitian sebelumnya, serta mengacu pada hipotesis teori, maka dalam penelitian ini peneliti merumuskan Hipotesis Nol (H0) dan Hipotesis Alternatif (Ha) yang kemudian akan dilakukan pengujian atas Hipotesis Nol (H0) tersebut untuk membuktikan apakah Hipotesis Nol (H0) tersebut ditolak atau gagal ditolak. Hipotesis tersebut dapat dinotasikan sebagai berikut :

\section{a. Hipotesis pertama}

$\mathrm{H}_{0} 1$ : Komite audit tidak berpengaruh signifikan terhadap kinerja perusahaan.

Ha1 : Komite audit berpengaruh signifikan terhadap kinerja perusahaan. b. Hipotesis kedua

$\mathrm{H}_{0} 2$ : Komite audit tidak berpengaruh signifikan terhadap manajemen laba.

Ha2 : Komite audit berpengaruh signifikan terhadap manajemen laba. c. Hipotesis ketiga

$\mathrm{H}_{0} 3$ : Manajemen laba tidak berpengaruh signifikan terhadap kinerja perusahaan

Ha3 : Manajemen laba berpengaruh signifikan terhadap kinerja perusahaan

Untuk melihat apakah manajemen laba termasuk sebagai variabel intervening pada pengaruh komite audit terhadap kinerja perusahaan. Pengujian ini menggunakan analisis hirarkikal yang digunakan oleh Baron and Kenny (1986) dalam Sriwardani (2006), dengan model dan langkah-langkah sebagai berikut:

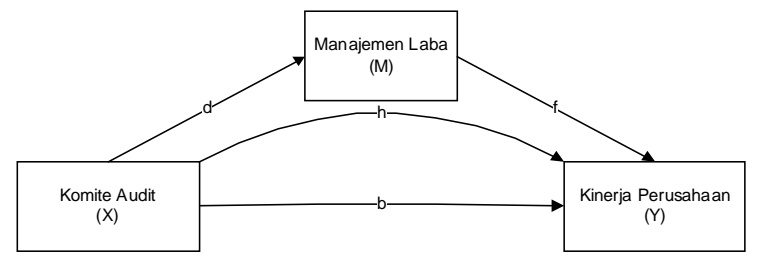

Gambar 4.1 Model Analisis Hirakikal

Sumber : dikembangkan dengan justifikasi penelitian terdahulu (2012) 


\section{Keterangan}

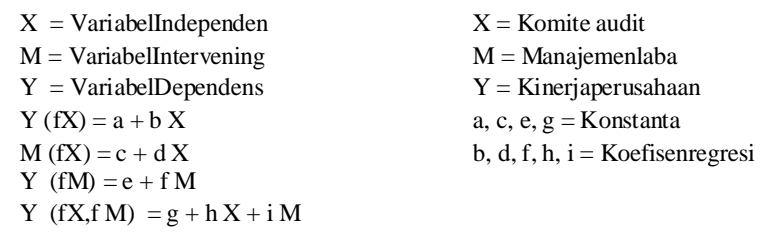

Suatu variable intervening dikatakan sebagai variabel intervening penuh jika:

$$
\begin{array}{lc}
b \neq 0 & d \neq 0 \\
f \neq 0, \text { also } j \neq 0 & h=0
\end{array}
$$

Suatu variabel intervening dikatakan sebagai variabel intervening sebagian jika:

$$
\begin{array}{ll}
b \neq 0 & d \neq 0 \\
f \neq 0, \text { also } \neq \neq 0 & h \neq 0, \text { bu } h<b
\end{array}
$$

\section{PEMBAHASAN}

\subsection{DESKRIPSI DATA PENELITIAN}

Deskripsi data penelitian dari masing-masing variabel yang meliputi nilai mean, standar deviasi, maksimum, minimum, data rasio tobins-q terendah (minimum) adalah 0,2200 dan yang tertinggi (maksimum) sebesar 1,9200, kemudian ratarata tobins-q sebesar 0,9994. Sementara standar deviasinya sebesar 0,4261 menunjukan simpangan data yang relativ kecil, karena nilainya yang lebih kecil daripada nilai mean-nya yaitu sebesar 0,9994 . Dengan tidak besarnya simpangan data menunjukan bahwa data variabel tobin-q dikatakan cukup baik.

Data rasio komite audit terendah (minimum) adalah 0,1400 dan yang tertinggi (maksimum) sebesar 0,6700, kemudian rata-rata tobins-q sebesar 0,4501 . Sementara standar deviasinya sebesar 0,1459 menunjukan simpangan data yang relativ kecil, karena nilainya yang lebih kecil daripada nilai mean-nya yaitu sebesar 0,4501. Dengan tidak besarnya simpangan data menunjukan bahwa data variabel komite audit dikatakan cukup baik.

Data rasio komite audit terendah (minimum) adalah -0,1800 dan yang tertinggi (maksimum) sebesar 0,2700, kemudian rata-rata tobins-q sebesar 0,0206 . Sementara standar deviasinya sebesar 0,1046 menunjukan simpangan data yang lebih besar, karena nilainya yang lebih besar daripada nilai mean-nya yaitu sebesar 0,0206 . Hal ini berarti rata-rata perusahaan yang diteliti memiliki manajemen laba yang rendah. Hal ini berarti memiliki kontrol kinerja yang baik, sehingga perusahaan akan lebih jujur dalam memberikan informasi laporan keuangannya kepada publik. Dengan nilai standar deviasi yang lebih besar dibandingkan dengan rata- ratanya menunjukkan ukuran penyebaran manajemen laba cenderung heterogen. 


\subsection{PENGUJIAN HIPOTESIS}

\subsubsection{Pengaruh Komite Audit terhadap Kinerja Perusahaan}

Setelah dilakukan pengujian asumsi klasik, maka selanjutnya dilakukan pengujian hipotesis dengan menggunakan analisis regresi. Pengujian hipotesis dilakukan untuk melihat apakah terdapat pengaruh signifikan komite audit terhadap kinerja perusahaan.

Nilai probabilitas 0,262 lebih besar dari á 0.05, maka dapat disimpulkan bahwa tidak terdapat pengaruh signifikan KA (komite audit) terhadap QT (kinerja perusahaan). Dengan demikian $\mathrm{H}_{0} 1$ diterima. Hasil ini memberikan makna bahwa secara statistik komite Audit tidak memiliki pengaruh signifikan terhadap kinerja perusahaan pada perusahaan yang termasuk dalam daftar efek syariah (DES). Variabel komite audit walaupun tidak berpengaruh signifikan namun tetap memiliki pengaruh kecil terhadap kinerja perusahaan yaitu sebesar 4,3\%, bisa dilihat dari nilai $\mathrm{R}^{2}$ sebesar 0,043 .

5.2.2 Pengaruh Komite Audit terhadap Manajemen Laba

Tabel 5.1 Ringkasan Uji Hipotesis Dua

\begin{tabular}{|c|c|c|c|c|c|c|c|c|c|}
\hline \multirow[t]{2}{*}{$\begin{array}{l}\text { Mo } \\
\text { del }\end{array}$} & $\mathrm{R}$ & $\mathrm{R}$ & $\begin{array}{l}\text { Adjus } \\
\text { ted R }\end{array}$ & $\begin{array}{c}\text { Std. } \\
\text { Error of }\end{array}$ & \multicolumn{5}{|c|}{ Change Statistics } \\
\hline & $\begin{array}{c}\text { R Square } \\
\text { Change }\end{array}$ & $\begin{array}{c}\text { F } \\
\text { Change }\end{array}$ & df1 & df 2 & $\begin{array}{c}\text { Sig. F } \\
\text { Change }\end{array}$ & $\begin{array}{l}\text { R Square } \\
\text { Change }\end{array}$ & $\begin{array}{c}\text { F } \\
\text { Cha } \\
\text { nge }\end{array}$ & $\begin{array}{c}\mathrm{df} \\
1\end{array}$ & df 2 \\
\hline 1 & $0,311(\mathrm{a}$ & 0,097 & 0,065 & 0,10114 & 0,097 & 0,097 & 1 & $\begin{array}{l}2 \\
9\end{array}$ & 0,089 \\
\hline
\end{tabular}

a Predictors: (Constant), KA

b Dependent Variable: DTACC

Sumber : data diolah (2012)

Nilai probabilitas (signifikansi) 0,089 lebih besar dari á sebesar 0,05, maka dapat disimpulkan bahwa tidak terdapat pengaruh signifikan KA (komite audit) terhadap DTACC (manajemen laba). Dengan demikian $\mathrm{H}_{0} 2$ diterima. Hasil ini memberikan makna bahwa secara statistik komite audit tidak mempunyai pengaruh signifikan terhadap manajemen laba pada perusahaan yang termasuk dalam daftar efek syariah (DES). Variabel komite audit walaupun tidak berpengaruh signifikan namun tetap memiliki pengaruh kecil terhadap kinerja perusahaan yaitu sebesar $9,7 \%$, bisa dilihat dari nilai $\mathrm{R}^{2}$ sebesar 0,097 .

\subsubsection{Pengaruh Manajemen Laba terhadap Kinerja Perusahaan}

Hasil pengujian berdasarkan tabel 4.9 dan 4.10 diatas menunjukan bahwa variabel manajeman laba tidak berpengaruh signifikan terhadap kinerja perusahaan dengan tingkat signifikansi $0,230>0,05$. dengan demikian $\mathrm{H}_{0} 3$ diterima. Hasil ini memberikan makna bahwa secara statistik manajemen laba tidak mempunyai pengaruh signifikan terhadap kinerja pasar perusahaan pada perusahaan yang termasuk dalam daftar efek syariah (DES). Variabel manajemen laba walaupun 
tidak berpengaruh signifikan namun tetap memiliki pengaruh kecil terhadap kinerja perusahaan yaitu sebesar $4,9 \%$, bisa dilihat dari nilai $\mathrm{R}^{2}$ sebesar 0,049 .

Tabel 5.2 Ringkasan Uji Hipotesis Tiga

\begin{tabular}{|r|c|c|c|c|c|c|c|c|c|}
\hline $\begin{array}{r}\text { Mo } \\
\text { del }\end{array}$ & $\mathrm{R}$ & $\begin{array}{c}\mathrm{R} \\
\text { Square }\end{array}$ & $\begin{array}{c}\text { Adjust } \\
\text { ed R } \\
\text { Square }\end{array}$ & $\begin{array}{c}\text { Std. Error } \\
\text { of the } \\
\text { Estimate }\end{array}$ & \multicolumn{5}{|c|}{ Change Statistics } \\
\hline & $\begin{array}{c}\text { R Square } \\
\text { Change }\end{array}$ & $\begin{array}{c}\mathrm{F} \\
\text { Change }\end{array}$ & $\mathrm{df1}$ & $\mathrm{df2}$ & $\begin{array}{c}\text { Chang } \\
\mathrm{e}\end{array}$ & $\begin{array}{c}\text { Square } \\
\text { Change }\end{array}$ & $\begin{array}{c}\text { Chang } \\
\mathrm{e}\end{array}$ & df1 & df2 \\
\hline 1 & $0,222(\mathrm{a})$ & 0,049 & 0,017 & 0,42259 & 0,049 & 1,507 & 1 & 29 & 0,23 \\
\hline
\end{tabular}

a Predictors: (Constant), DTACC

b Dependent Variable: QT

Sumber : data diolah (2012)

5.2.4 Manajemen Laba sebagai Variabel Intervening pada Pengaruh Komite Audit terhadap Kinerja Perusahaan

Pengujian hipotesis keempat dilakukan untuk melihat apakah manajemen laba termasuk variabel intervening pada pengaruh komite audit terhadap kinerja pasar perusahaan.

Berdasarkan hasil analisis secara keseluruhan menunjukkan bahwa komite audit tidak berpengaruh secara langsung dan signifikan terhadap manajemen labamaupun terhadap kinerja keuangan. Pengaruh secara langsung dan signifikan serta terjadi pada mekanisme manajemen labaterhadap kinerja keuangan. Dengan demikian manajemen laba bukan sebagai variabel intervening (pemediasi) penuh hubungan antara komite audit dengan kinerja pasar perusahaan.

Tabel 5.3 Ringkasan Kriteria Uji

\begin{tabular}{|c|r|l|}
\hline Koefisien & \multicolumn{2}{|c|}{ Hasil } \\
\hline B & 0,607 & b ? 0 \\
\hline D & $-0,223$ & d ? 0 \\
\hline F & $-0,905$ & f ? 0 \\
\hline H & 0,449 & h ? 0, h<b \\
\hline J & $-0,711$ & j ? 0 \\
\hline
\end{tabular}

Sumber : data diolah (2012)

Dari hasil ringkasan kriteria uji diatas (tabel 4.9), terlihat bahwa koefisien regresi h adalah sebesar 0,449 , tidak sama dengan 0 dan lebih kecil dari koefisien regresi b sebesar 0,607. Dengan demikian pengaruh komite audit terhadap kinerja keuangan harus melalui manajemen laba yang memediasi sebagian yang berarti manajemen laba berlaku sebagai variabel intervening sebagian.

$$
\text { 5.3 PEMBAHASAN }
$$

\subsubsection{Pengaruh Komite Audit terhadap Kinerja Perusahaan}

Pihak internal maupun eksternal suatu perusahaan selalu mengharapkan kinerja perusahaan selalu meningkat. Hadirnya komite audit diharapkan memiliki 
pengaruh untuk meningkatkan kinerja perusahaan yang mengeluarkan saham syariah yang masuk dalam daftar efek syariah (DES).

Hasil penelitian ini menunjukan bahwa komite audit tidak memiliki pengaruh signifikan terhadap kinerja perusahaan, hal ini dapat dilihat pada tabel 4.4 dari tingkat signifikansinya $0,262>0,05$, dengan demikian, hasil penelitian ini berbeda dengan hasil penelitian Felo (2003) dan Effendi (2005), Xie, Davidson, Dadalt (2003), Veronica dan Bachtiar (2004), Wedari (2004), dan Wilopo (2004), namun sesuai dengan hasil penelitian yang dilakukan oleh Nuryanah (2004), Mayangsari (2003) yang meneliti pengaruh keberadaan komite audit terhadap integritas laporan keuangan, disimpulkan bahwa keberadaan komite audit berhubungan negatif dengan integritas laporan keuangan. Dan Nuryanah (2004) dalam Effendi (2005) menemukan bahwa komite audit tidak mempengaruhi nilai perusahaan secara signifikan. Goodstein \& Boeker (1991) dalam Purwati (2006), menyatakan bahwa pengangkatan dewan komisaris independen sebagai ketua komite audit oleh perusahaan mungkin hanya dilakukan untuk pemenuhan regulasi saja tapi tidak dimaksudkan untuk menegakkan Good Corporate Governance (GCG) di dalam perusahaan. Padahal Komite audit mempunyai peran yang sangat penting dan strategis dalam hal memelihara kredibilitas proses penyusunan laporan keuangan seperti halnya menjaga terciptanya sistem pengawasan perusahaan yang memadai serta dilaksanakannya good corporate governance. Dengan berjalannya fungsi komite audit secara efektif, maka control terhadap perusahaan akan lebih baik, sehingga konflik keagenan yang terjadi akibat keinginan manajemen untuk meningkatkan kesejahteraannya sendiri dapat diminimalisasi. Akan tetapi fungsi pengawasan yang seharusnya menjadi tanggung jawab anggota komite audit sebagai wakil dari dewan komisaris menjadi tidak efektif karena pembentukan komite audit hanya untuk memenuhi regulasi.

Keberadaan komite audit independen yang memiliki keahlian dalam bidang akuntansi dan keuangan adalah sinyal persepsi kredibilitas dan kualitas laba perusahaan yang lebih baik. Laba yang kredibel dan berkualitas baik akan direspons lebih kuat dan menunjukan kinerja perusahaan yang baik (Teoh dan Wong, 1993; Choi dan Jeter, 1990; Anderson et al., 2003; Bryan et al., 2004 dalam Purwati, 2006). Namun berdasarkan data yang ada, Sebagian besar anggota komite audit ternyata tidak memiliki background pendidikan akuntansi atau keuangan, sehingga fungsi seperti disebutkan diatas belum terpenuhi. selanjutnya sebagian besar komisaris independen terdiri dari pejabat publik ataupun tokoh masyarakat, yang belum tentu memiliki keahlian dalam kontek manajemen perusahaan. Mereka juga menjabat sebagai komisaris dan direksi di perusahaan lain (cross-directorships), baik perusahaan yang berkaitan maupun perusahaan lain. Sehingga hal tersebut mengindikasikan bahwa keandalan kinerja komite audit kurang maksimal, sehingga belum mempengaruhi secara signifikan terhadap kinerja perusahaan.

Dari beberapa anggota komite audit yang ada pun, tidak semua anggota memiliki waktu dalam rangka memberikan fokus pengawasan terhadap kinerja manajerial. Hal ini terlihat dari proporsi kehadiran rapat komite audit, dimana 
anggota komite audit tidak secara keseluruhan menghadiri rapat komite audit. Aktifnya peranan komite audit dalam praktek memang sangat tergantung pada lingkungan yang diciptakan oleh perusahaan yang bersangkutan.

Komisaris independen sebagai ketua komite audit seringkali dianggap tidak memiliki manfaat. Hal ini dapat dilihat dalam fakta, bahwa banyak anggota Dewan Komisaris independen tidak memiliki kemampuan, dan tidak dapat menunjukkan independensinya, sehingga dalam banyak kasus, Dewan Komisaris independen juga gagal untuk mewakili kepentingan stakeholders lainnya selain daripada kepentingan pemegang saham mayoritas, (Sam'ani, 2008).

Selanjutnya komite audit belum maksimal mengungkapkan laporanlaporan tentang tugas dan tanggung jawabnya pada laporan keuangan tahunan seperti melakukan penelaahan atas pelaksanaan pemeriksaan auditor internal pada laporan annual report. Sehingga cukup sulit untuk menilai kinerja komite audit dalam mengemban amanahnya. Komite audit juga masih mengalami kendala-kendala seperti masalah komunikasi dengan dewan komisaris, dewan direksi, auditor internal dan eksternal serta pihak lain sebagai aspek yang penting dalam keberhasilan komite audit (Paramita, 2008). Dari beberapa alasan tersebut diduga sebagai masalah yang menyebabkan tidak memberikan pengaruh signifikan terhadap kinerja perusahaan.

Alasan selanjutnya mungkin disebabkan karena keberadaan komite audit merupakan hal yang baru bagi perusahaan, mengingat peraturan pemerintah dan bapepam ini belum lama diterbitkan. Akibatnya pembentukan komite audit yang baru ini juga masih mengalami kendala-kendala seperti masalah komunikasi dengan dewan komisaris, dewan direksi, auditor internal dan eksternal serta pihak lain sebagai aspek yang penting dalam keberhasilan kerja komite audit. (Effendi, 2005). Dengan adanya kendala-kendala yang masih dihadapi, sehingga belum efektif dan hal ini tidak memberikan pengaruh yang signifikan terhadap kinerja perusahaan.

\subsubsection{Pengaruh Komite Audit terhadap Manajemen Laba}

Tidak signifikannya komite audit terhadap manajemen laba, disebabkan karena dalam pengukuran komite audit, hanya didasarkan pada informasi pengungkapan komite audit pada laporan keuangan tahunan perusahaan sesuai peraturan Bapepam No. IX.1.5 tentang pembentukan dan pedoman pelaksanaan kerja komite audit No. Kep-29/PM/2004 tanggal 24 September 2004) juncto Peraturan Bapepam No. X.K.6 tentang Kewajiban Penyampaian Laporan Tahunan Bagi Emiten atau Perusahaan Publik, menyebutkan bahwa keanggotaan komite audit sekurang-kurangnya terdiri dari 3 (tiga) orang anggota, seorang diantaranya merupakan Komisaris Independen Perusahaan Tercatat yang sekaligus merangkap sebagai ketua Komite Audit, sedangkan anggota lainnya merupakan pihak ekstern yang independen dimana sekurang-kurangnya satu diantaranya memiliki kemampuan dibidang akuntansi dan atau keuangan. Berdasarkan data yang ada sebagian besar perusahaan dalam penelitian ini tidak memiliki background pendidikan akuntansi dan keuangan, beberapa dari mereka ada yang dari hukum, teknik dll. Hal ini yang memungkinkan adanya 
ketidak efektifan kinerja komite audit, sehingga keberadaannya tidak memiliki pengaruh signifikan.

Hal tersebut sesuai DeZoort dan Salterio (2001) menguji apakah komite audit yang anggotanya memiliki pengalaman tata kelola perusahaan yang baik serta pengetahuan pelaporan keuangan dan audit mempengaruhi kebijakannya ketika terdapat selisih pendapat antara manajemen dan auditor. Hasil penelitian adalah semakin banyak pengalaman komisaris independen dan semakin banyak pengetahuan audit berhubungan dengan auditor semakin besar anggota komite mendukung auditor. Sebaliknya, anggota yang memiliki pengalaman sebagai dewan komisaris dan manajemen senior cenderung mendukung manajemen. Temuan ini berimplikasi bahwa komite seharusnya beranggotakan pihak independen serta memiliki pengetahuan audit dan pelaporan keuangan.

Kemudian independensi anggota komite audit sekaligus juga sulit di deteksi. Mungkin hal ini yang menyebabkan komite audit belum secara maksimal melaksanakan fungsinya sehingga keberadaan komite audit tidak memiliki pengaruh signifikan terhadap pencegahan terjadinya manajemen laba. Hasil ini sejalan dengan pendapat Herwidayatmo (2000) dalam artikel FCGI tentang peranan Dewan Komisaris dan Komite Audit dalam Corporate Governance yang menyatakan bahwa independensi Dewan Komisaris di Indonesia sangat diragukan mengingat posisi anggota dewan Komisaris diberikan sebagai rasa penghargaan semata maupun berdasarkan hubungan kekeluargaan atau kenalan dekat. Vincentus Anthony dalam Media Akuntansi yang tidak yakin Komite Audit efektif dalam menjalankan fungsinya. Dikatakan bahwa semasa Komite Audit masih mendapat manfaat/benefit dari perusahaan, independensinya sulit diwujudkan. Baysinger dan Butler (1985) mengemukakan bahwa independensi serta komposisi anggota komite audit merupakan faktor penting dalam kesuksesan komite audit.

Dengan demikian perusahaan yang memiliki komite audit belum tentu perusahaan itu telah memenuhi peraturan yang berlaku, bahkan pada sebagian besar perusahaan yang diteliti yang memiliki komite audit belum $100 \%$ sesuai peraturan yang berlaku, hal ini yang memungkinkan keberadaan komite audit belum mampu memberikan kontrol secara optimal untuk mengurangi manajemen laba yang dilakukan oleh para manajer.

Hasil penelitian tersebut diatas juga menunjukan bahwa komite audit memiliki pengaruh negatif terhadap manajemen laba, yang dapat dilihat nilai koefisien regresi komite audit -0,223 dengan tingkat signifikansi 0,089 yang berarti bahwa komite audit tidak mempengaruhi manajemen laba secara signifikan. Walaupun bernilai negatif $(-0,223)$, hal ini justru sesuai dengan pendapat dengan penelitian Klien (2002) menguji apakah komite audit dan karakteristik dewan komisaris berhubungan dengan manajemen laba. Hasil temuan membuktikan bahwa terdapat hubungan negatif antara komite audit independen dan akrual tidak normal. Hasil ini menunjukkan bahwa struktur dewan yang independen terhadap CEO efektif dalam memonitor proses pelaporan akuntansi keuangan perusahaan. Klien menjelaskan bahwa komite audit bertugas sebagai penengah dua pihak untuk menimbang dan sebagai 
penghubung pandangan yang berbeda antara manjamen dan auditor untuk mencapai keseimbangan akhir sehingga laporan lebih akurat. Hasilnya menunjukkan bahwa perusahaan yang memiliki komite audit, kecenderungan perusahaan tidak melakukan manajemen laba. Hal ini sesuai dengan pendapat yang dikemukakan Dechow et al., (1996) yang menyatakan bahwa perusahaan dengan adanya komite audit yang berkualitas mampu membatasi dilakukannya manajemen laba dalam perusahaan. Jadi keberadaan komite audit menurunkan terjadinya manajemen laba.

\subsubsection{Pengaruh Manajemen Laba terhadap Kinerja Perusahaan}

Hasil Penelitian tersebut diatas (tabel 4.6 ) menunjukan bahwa dengan koefisien regresi yang bernilai negatif $(-0,905)$, maka hubungan manajemen laba terhadap kinerja perusahaan tidak signifikan, dengan demikian penelitian ini tidak sesuai dengan pendapat yang dikemukakan Scott (2003) dan Paramita (2008), yaitu manajemen laba yang dilakukan perusahaan dapat bersifat good (efisien), namun penelitian ini sesuai dengan penelitian Darmawati et al., (2005), Hidayah (2005) yang menemukan tidak terdapat hubungan manajemen laba dengan tobin's $Q$ kinerja perusahaan, itu artinya manajemen laba belum bisa mempengaruhi kinerja perusahaan, masih banyak faktor lain seperti growth (pertumbuhan), size (ukuran perusahaan), asset (aktiva) yang dapat mempengaruhi kinerja perusahaan.

5.3.4 Manajemen Laba sebagai Variabel Intervening pada Pengaruh Komite Audit terhadap Kinerja Pasar perusahaan.

Hasil penelitian sebelumnya yang diantaranya dilakukan oleh Klein (2002) memberikan bukti secara empiris bahwa perusahaan yang membentuk komite audit independen melaporkan laba dengan kandungan akrual diskresioner yang lebih kecil dibandingkan dengan perusahaan yang tidak membentuk komite audit independen. Effendi (2005) menunjukan bahwa adanya pengaruh antara komite audit terhadap kinerja perusahaan. disamping itu ada dasar teori yang menyatakan bahwa adanya komite audit akan mempengaruhi kinerja perusahaan, namun menurut Mayangsari (2003) yang meneliti pengaruh keberadaan komite audit terhadap integritas laporan keuangan, disimpulkan bahwa keberadaan komite audit berhubungan negatif dengan integritas laporan keuangan. Sedangkan Nuryanah (2004) dalam Effendi (2005) menemukan bahwa komite audit tidak mempengaruhi nilai perusahaan secara signifikan. Dan penelitian ini menunjukan bahwa komite audit tidak mempengaruhi secara signifikan terhadap kinerja perusahaan.

Berdasarkan hasil ringkasan kriteria uji diatas (tabel 4.9) menunjukan bahwa komite audit walaupun tidak mempunyai pengaruh signifikan terhadap kinerja perusahaan, namun pegaruhnya dapat melalui manajemen laba yang dapat dilihat dari hasil kriteria uji yang dilakukan menunjukan bahwa koefisien regresi h sebesar 0,449. tidak sama dengan 0 dan lebih kecil dari koefisien regresi b sebesar 0,607. Hal ini berarti bahwa manajemen laba merupakan variabel intervening sebagian, yang menunjukkan bahwa informasi tentang adanya komite audit dengan menekan terjadinya manajemen laba maka komite audit 
langsung akan mempengaruhi kinerja perusahaan yang dalam hal ini kinerja pasar perusahaan.

Dengan demikian setiap perusahaan diharapkan dalam proses pengangkatan anggota komite audit harus teliti dan sesuai dengan kualifikasi peraturan BAPEPAM no XI 1.5 tahun 2004 agar para anggota melakukan tugasnya sesuai dengan peraturan tersebut, sehingga keberadaan komite audit akan mempengaruhi dan meningkatkan kinerja perusahaan di masa yang akan datang dan praktik manajemen laba bisa dicegah.

Berdasarkan hasil analisis secara keseluruhan menunjukkan bahwa komite audit tidak berpengaruh signifikan terhadap manajemen labamaupun terhadap kinerja keuangan. Dengan demikian manajemen laba bukan sebagai variabel intervening penuh melainkan variabel intervening sebagian pengaruh antara komite audit dengan kinerja pasar perusahaan.

\section{PENUTUP}

\subsection{KESIMPULAN}

Penelitian ini berusaha untuk menguji pengaruh komite audit terhadap kinerja perusahaan melalui manajemen laba sebagai variabel intervening dengan sampel perusahaan yang mengeluarkan saham syariah dan masuk dalam daftar efek syariah (DES) yang tercatat di Bursa Efek Indonesia (BEI). Berdasarkan hasil pengujian menunjukkan bahwa variabel komite audit tidak berpengaruh signifikan terhadap kinerja keungan. Manajemen laba bukan sebagai variabel intervening penuh, namun variabel intervening sebagian terhadap pengaruh komite audit terhadap kinerja perusahaan. Adapun hasil penelitian secara ringkas dapat dijabarkan sebagai berikut:

1. Komite audit (KA) tidak mempunyai pengaruh signifikan terhadap kinerja perusahaan. Probabilitas menunjukkan lebih besar dari 0,05 yaitu sebesar 0,262 , artinya bahwa variabel komite audit tidak mempunyai pengaruh yang signifikan terhadap kinerja peruahasaan (tobins q). Dengan demikian dapat disimpulkan bahwa hipotesis pertama yang menyatakan Komite audit (KA) secara signifikan berpengaruh terhadap kinerja dapat diterima atau $\mathrm{H}_{\mathrm{a}} 1$ ditolak danH $\mathrm{H}_{0} 1$ diterima.

2. Komite audit (KA) tidak mempunyai pengaruh signifikan terhadap manajemen laba. Probabilitas menunjukkan lebih besar dari 0,05 yaitu sebesar 0,089 , artinya bahwa variabel komite audit tidak mempunyai pengaruh yang signifikan terhadap manajemen laba (DTACC). Dengan demikian dapat disimpulkan bahwa hipotesis kedua yang menyatakan komite audit (KA) secara signifikan berpengaruh terhadap manajemen laba (DTACC) tidak dapat diterima atau $\mathrm{H}_{2} 2$ ditolak dan $\mathrm{H}_{0} 2$ diterima.

3. Manajemen laba (DTACC) tidak mempunyai pengaruh signifikan terhadap kinerja perusahaan. Probabilitas menunjukkan lebih besar dari 0,05 yaitu sebesar 0,230, artinya bahwa variabel manajemen laba (DTACC) tidak mempunyai pengaruh yang signifikan terhadap kinerja peruahasaan. 
Dengan demikian dapat disimpulkan bahwa hipotesis ketiga yang menyatakan manajemen laba (DTACC) secara signifikan berpengaruh terhadap kinerja tidak dapat diterima atau $\mathrm{Ha} 3$ ditolak dan $\mathrm{H}_{0} 3$ diterima.

4. Manjemen laba merupakan variabel intervening sebagian pada pengaruh komite audit terhadap kinerja perusahaan. Hal ini bisa dilihat bahwa koefisien regresi h adalah sebesar 0,449 , tidak sama dengan 0 dan lebih kecil dari koefisien regresi b sebesar 0,607 yang artinya manajemen laba merupakan variabel intervening sebagian.

\subsection{KETERBATASAN PENELITIAN}

Dalam penelitian ini terdapat beberapa keterbatasan yang mungkin mempengaruhi hasil penelitian. Adapun beberapa keterbatas adalah :

1. Jumlah pengamatan yang digunakan didalam penelitian ini relatif sedikit dan periode yang pendek, yakni terbatas pada 31 perusahaan yang mengeluarkan saham dan masuk daftar efek syariah (DES) yang listed di BEI tahun 2010, hal ini terkait dengan adanya keterbatasan data. Padahal masih banyak perusahaan yang masuk daftar efek syariah yang mungkin dapat dijadikan sebagai objek penelitian. Sehingga hasil penelitian tidak dapat di generalisir pada kontek kelompok industri yang lebih luas di Indonesia.

2. Penelitian ini hanya menggunakan tobins-q sebagai proksi dari salah satu kinerja pasar perusahaan, oleh karena itu hasil penelitian ini belum mencerminkan pengaruh kinerja perusahaan seutuhnya.

3. Variabel komite audityang ada belum dapat mengukur secara komprehensif realitas dari praktik pengungkapan kinerja komite audit, sehingga perlu adanya indeks tertentu yang mencerminkan praktik komite auditsecara lebih tepat. Selain itu karakteristik komite audit secara spesifik tidak dimuat dalam annual report, misalnya kompetensi, keahlian, latar belakang pendidikan, pengalaman komite audit. Sehingga dibutuhkan untuk metode konfirmatif kepada pihak perusahaan terhadap poin-poin yang ada pada peraturan tersebut. Hal ini membutuhkan waktu biaya yang cukup banyak.

4. Penilaian item pengungkapan komite audit bersifat subyektif, menurut pada pandangan peneliti, mungkin akan didapat hasil yang berbeda dari peneliti lainnya.

$$
\text { 6.2 SARAN }
$$

Saran untuk penelitian selanjutnya adalah :

1. Untuk peneliti lanjutan disarankan untuk menambah jumlah sampel penelitian dan juga menggunakan jenis perusahaan yang masuk satu kelompok perusahaan dan menggunakan periode penelitian yang lebih panjang sehingga hasilnya lebih dapat digeneralisir sesuai dengan kelompok perusahaan.

2. Nilai koefisien determinasi yang masih rendah dalam penelitian ini hendaknya dijadikan pertimbangan oleh peneliti berikutnya untuk memasukkan variabel yang secara teoritis bisa dimasukkan dalam model 
persamaan regresi yang ada.

3. Agar karakteristik komite audit secara spesifik bisa diketahui misalnya kompetensi, keahlian, latar belakang pendidikan, independensi dan anggota komite audit. maka dibutuhkan untuk menggunakan metode konfirmasi kepada pihak perusahaan terhadap poin-poin yang ada pada peraturan tersebut. Walaupun hal ini membutuhkan waktu dan biaya yang cukup banyak namun hal ini akan dapat bersifat objektif.

\section{DAFTAR PUSTAKA}

Agung, S. (2005). "Pengaruh Komite Audit terhadap Kualitas Laba". Skripsi SI, Jurusan Akuntansi Universitas Udayana. , Bali.

Alijoyo, A. E. (2004). Review of Corporate Governance in Asia: Corporate Governance in Indonesia . Forum for Corporate Governance in Indonesia .

Anderson, K. D. (2003). Boards of Directors, Audit Committees, and the Information Content of Earnings. SSRN Working Paper, September.

Audit., B. E. (2001). Paten No. Surat Edaran No: SE- 008/BEJ/12-2001.

Bapepam. (2004). Paten No. Surat Edaran Bapepam No.SE.03/PM/2000. Pembentukan Komite Audit.

Baron, R. M. (1986). The Moderator-Mediator Variable Distinction in Social Psycologycal reseach, Conseptual, Strategic and Statistcal Konsiderations . Journal of Personality and Social Psycology, 51, 1173,1182 .

Bradbury, M. E. (2004.). "Board Characteristics, Audit Committee Characteristics and Abnormal Accruals". Working Paper. Unitec New Zealand dan National University of Singapore.

Bryan, D. M. (2004). The Influence of Indeendent and Effective Audit Committee on Earning Quality. http://ssrn.com, diakses pada January 2012.

Carcello, J. a. (2003). "Audit Committees Characteristics and Auditor dismissals Following "New" Going Concern Report". The Accounting Review, Vol.78 No.1, January.

Debby Fitriasari SE. AK, M. (2007). "Pengaruh Aktivitas Dan Financial Literacy Komite Audit terhadap Jenis Manajemen Laba". Simposium Nasional Akuntansi X, , Juli. 
Dechow, P. M. (1995). Detecting Earnings Management. The Accounting Review , April. Vol. 70. No. 2.

Effendi, M. A. (2005). Peranan Komite Audit dalam Meningkatkan Kinerja Perusahaan . Jurnal Akuntansi Pemerintah, Volume 1, 1.

Ghozali, I. (2005). Aplikasi Analisis Multivariate dengan Program SPSS. Edisi 3. Semarang: Badan Penerbit Universitas Dionegoro.

Gudjarati, D. (1995). Basic Econometrics. Edisi 3. . New York: McGraw-hill.

Hastuti, T. D. (2005). "Hubungan Antara Good Corporate Governance dan Stuktur Kepemilikan Dengan Kinerja Keuangan”. Simposium Nasional Akuntansi VIII , September.

Herlambang, R. S. (2003). "Pengaruh Earning Power (EP), Return on Equity (ROE), Deviden Payout Ratio (DPR), dan tingkat Suku Bunga Deposito terhadap Return Saham (Studi Kasus Perusahaan Otomotif pada Sektor Industri Manufaktur di BEJ)". Tesis S2, Universitas Diponegoro. Semarang .

Klein, A. (2002). Audit Commite, Board of Director. Characteristics Economics (33), 375-400.

Ludovicus. (2007). Memahami Lebih Jauh Aspek Earnings Management,Financial Shenanigans,dan Rekayasa Keuangan. Economic Business \& Accounting Review vol.II.

Mayangsari, S. d. (2002). Reaksi pasar Modal Indonesia terhadap Pembentukan Komite Audit. Proceeding Simposium Surviving Strategies to Cope with the Future, Fakultas Ekonomi Universitas Atma Jaya Yogyakarta

McMullen, D. (1996). "Audit Committee Perforance: An Investigation of the consequences Associated with Audit Committes". Auditing: A Journal of Practice \& Theory, Vol. 15, No. 1 p., 88-103.

Nurrohmah. (2010). pengaruh Earning Power, Laverage, dan Ukuran Perusahaan terhadap Manajemen Laba. Skripsi Akuntansi STEI SEBI , 12-13.

Paramita R.S. (2008). "Hubungan Komite Audit terhadap Kinerja Keuangan melalui GCG sebagai variabel intervening". Skripsi Akuntansi SI, UII. , Yogjakarta.

Purwati, A. (2006.). "Pengaruh Karakteristik Komite Audit Terhadap Ketepatan Waktu Pelaporan Keuangan pada Perusahaan Publik yang Tercatat di 
BEJ”. Tesis S2, Magister Sains UNDIP. , Semarang.

Rahayu, S. (2010). Pengaruh Kinerja Keuangan terhadap Nilai Perusahaan dengan Pengungkapan Corporate Social Responsibility dan Good Corporate Governance sebagai Variabel Pemoderasi. Skripsi Akuntansi Fakultas ekonomi UNDIP , 32-33.

Sam’ani. (2008.). "Pengaruh Good CorporateGovernance dan Laverage terhadap Kinerja Keuangan pada Perbankan yang terdaftar di bursa efek Indonesia (BEI) tahun 2004-2007”. Tesis S2, Magiter Managemen UNDIP. , Semarang.

Scott, W. R. (1997). Financial Accounting Theory. New Jersey:: Prentice-Hall.

Sriwardani. ( 2006). Pengaruh Pertumbuhan Perusahaan Terhadap Kebijaksanaan Struktur Modal dan Dampaknya Terhadap Perubahan Harga Saham pada Perusahaan Manufaktur Tbk. Tesis, Universitas Sumatra Utara, pp.3536.

Sugiono, D. (2007). Metode Penelitian Bisnis. Bandung: Alfabeta.

Surya, I. d. (2006). Penerapan Good Corporate Governance: Mengesampingkan Hak-hak Istimewa Demi Kelangsungan Usaha. Jakarta: Kencana.

Surya, I. d. (2006). Penerapan Good Corporate Governance: Mengesampingkan Hak-hak Istimewa Demi Kelangsungan Usaha. Jakarta: Kencana.

Tjager, I. F. (2003). Corporate Governance: Tantangan dan Kesempatan bagi Komunitas Bisnis Indonesia. Pearson Education-Prentice Hall .

Widyaningdyah, A. U. (2001). Analisis Faktor-Faktor yang Berpengaruh Terhadap Earnings Manajemen Perusahaan yang Go Public di Indonesia. Jurnal Akuntansi \& Keuangan, Vol. 3. No.2. November. 